\title{
古代地中海文明圈におけるモデュールの技法について \\ ウィトルーウィウスの「建築十書」の記述とエジプトの建築関連資料にみられる設計技術の比較分析を中心に ON THE MODULE SYSTEM OF THE ANCIENT MEDITERRANEAN CIVILIZATION
}

A comparative analysis of the descriptions in Vitruvius' "De Architectura" and the Egyptian Architectural Media

\author{
安 岡 義 文*1
}

\section{Yoshifumi YASUOKA}

\begin{abstract}
This paper aims to elucidate the origin of the module system in the Ancient Mediterranean civilization. In the first part, the essence of the Greek and the Roman design method is extracted from the Vitruvian treatise: "De Architectura". In the following part, the Egyptian design method is reconstructed through the analysis of the architectural media found in Egypt. The comparative analysis, in the last part, demonstrates clear metaphysical differences between the Doric system and the Ionic system of design, as well as striking similarities between the Doric system and the Egyptian system used for the naos-shrine.
\end{abstract}

Keywords : M odule system, Symmetria, D esign theory, Vitruvius, Ancient M editerranean cultures, Architectural philosophy モデュール・システム，シュムメリア，設計理論，ウイトルーウィウス，古代地中海文明圈，建築思想

\section{1. はじめに}

ローマ人建築家マルクス・ウィトルーウィウス・ポッリオは、紀 元前 20 年頃に著した「建築十書」の中で、「比例（ANALOGIA/ proportiones rationes)」の技法を設計理論の中核として扱い、これを 「シュムメトリア（SYMMETRIA）」と呼んだ。注1)シュムメトリアと は、ギリシア語で「寸法を纏めること」を意味し、「あらゆる建物に おいて肢体および全体が一定部分の度に従うことで」あり、「容姿の 立派な人間に似るように各肢体が正確に割付けられている」（第 3 書 第 1 章第 1 節) ことであった。注2) 具体的には、「モデュルス (EMBATER/ modulus ; 以下モデュール)」と呼ばれる基準となる部位の寸法を建 物の全体から比例的に求め、その他の部位をモデュールの倍数及び 分数で表し、寸法体系を構築することを意味した。この技法は、イ タリア・ルネッサンス期に生まれた多くの建築書に継承されただけ でなく、レオナルド・ダ＝ヴィンチの「ウィトルーウィウス的人体図」 注3)、アルブレヒト・デューラーの人体プロポーションの研究注4)、あ るいは近代のル＝コルビュジエの「モデュロール論」注5) などに代表 されるように、西洋美術におけるデザイン理論の伝統として重んじ られてきた。

しかし一方で、古代地中海文明で用いられていたシュムメトリア の技法は、未だ正しく理解されているとは言えない。「建築十書」が 再発見され、ウィトルーウィウス研究が盛んになったルネッサンス 期では、レオン・バッティスタ・アルベルティに代表される研究者 らが、「建築十書」に記された比例を用いた設計技法における数值関 係や多用されたギリシア語の借用語とラテン語の専門用語の解釈に 大きな関心を抱き、最終的には独自の理論と比例体系を主張する執
筆活動へと展開していった。注6 また 18 世紀末にギリシア・ローマ での遺跡調查が行われるようになってから 19 世紀後半までのヨー ロッパ各国の研究者たちは、遺構の実測值や図面からの採寸值と、 ウィトルーウィウスのシュムメトリアの技法に見られる比例の数值 関係を比較した結果、両者のギャップに苛まれてきた。注7) 19 世紀末 から 20 世紀後半にかけては、遺構の実測值や図面を分析して、黄金 比や幾何学的操作から生まれる特定のプロポーションの存在を証明 しようとする研究注8)や、その遺跡の計画寸法や設計技法を復元しよ うとする研究注9)が頻繁に行われるようになった。

独自理論の創作のために「建築十書」のシュムメトリアの技法を 扱った例はよいとして、ギリシア・ローマ建築の設計理論や、その 具体的遺構の寸法計画を復元した既往研究が採用してきた研究方法 には、致命的な欠陥がある。それは、理論で示されたものの検証を 実際の遺構のみで行うことである。概して、古代の建築事業において、 施工時の計画の変更、竣工から今日に至るまでに起きたであろう数々 の変化（増改築、崩落、災害、修繥など）を考慮して、事業の最初 期の理想的デザインの正確な像へと辿り着くことは、限りなく不可 能に近い。多くの研究者たちは、遺構の寸法分析を通して、己が見 たい数值関係を見出していたにすぎず、その結果として、これまで 一つの遺構に対して同様に不確からしい復元案が複数提示されてき た。この問題について、森田慶一やジェイムズ・ジョン・クールト ンらが、1970 年代にすでに指摘しているように、遺構のみの分析か ら窥えるのは、計画された可能性の高い寸法部位と、それらの比例 関係の傾向の特定に留まる。注10) また、ごく僅かな例を除いて瓜二つ の遺構が存在しないように、ウィトルーウィウスの提示した一般理
*1 東京大学大学院工学系研究科建築学専攻 日本学術振興会特別研究員 SPD・哲博
Superlative Postdoctoral Fellow of JSPS, Dept. of Architecture, Faculty of

Engineering, The University of Tokyo, Dr.Phil. 
Ionic Order: Vitruvius, De Architectura, Book III, 5.1-15.

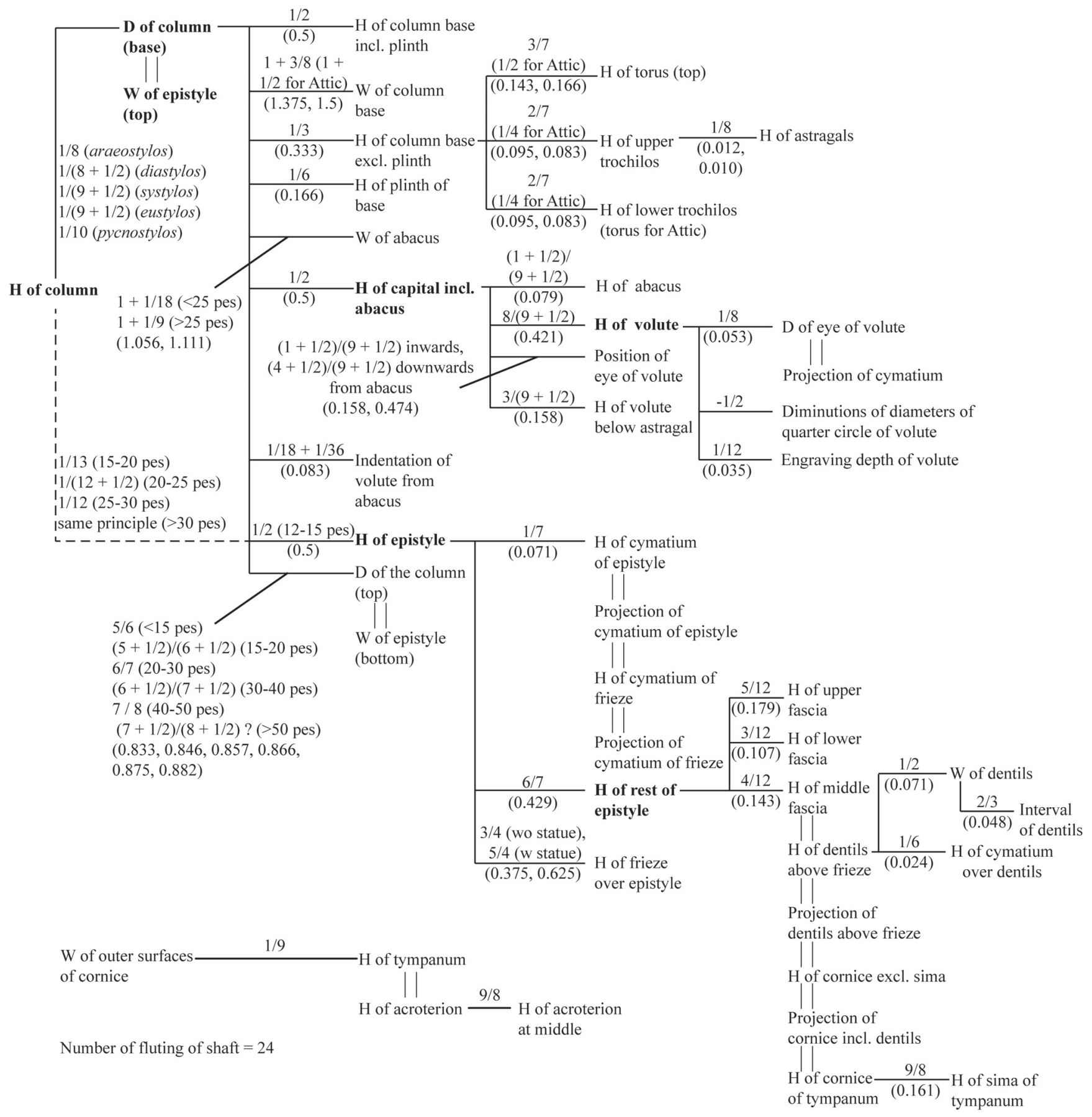

Fig. 1 Diagram of the module system of the lonic temple as described by Vitruvius (Book III, 5.1-15)

論と遺構に見られる部材同士の比例関係が一致しないことを憂う必 要もない。注11) なぜなら、注目すべきは比例の数值関係ではなく、む しろ比例体系を用いて建築全体を統御しようとする思想そのものに あるからであり、これについては、すでに森田や元良勲が指摘して いる通りである。注 12$)$

この意味において、先人たちの果敢な試みが徒労に終わったのは 必然であり、その結果、今日では、ウィトルーウィウスを研究する 者の多くは、設計技法の分析を避けるまでになっている。今日、我々 がこの停滞しているテーマの研究を進め、シュムメトリアの技法の 意味を正しく理解するためには、別のアプローチが不可欠である。
このような背景を鑑み、筆者は本稿において以下の 2 点に配慮しな がら、同テーマの分析を進める。第一に、ウィトルーウィウスの「建 築十書」におけるモデュールの技法に関する記述から寸法系統図を 構築し、モデュールの技法の構造的特質を読み解く。次に、建築事 業の計画段階に密接に関係がある建築関連資料（設計図、模型、文 書など）が出土しているエジプト文明を比較考察の対象として、地 中海文明圏の設計技術を総合的に分析する。注13) この両者を比較分析 することによって、海を隔てた両文化圈の設計理論にみられる共通 点と相違点を抽出し、古代地中海文明圈において設計理論がどのよ うに共有され変容を遂げていったかを明らかにする。 


\section{2.「建築十書」にみられるシュムメトリアの技法}

\section{2. -1. イオニア式のシュムメトリア}

ウィトルーウィウスは、神殿建築のシュムメトリアの技法を用いた 設計方法の説明にあたって、イオニア式を、「三つの様式のうちで比 例において一ばん精緻な (subtilissimas) モドゥルス量をもつ」（第 4 書 序章第 2 節）と位置付けて、最初に最も詳細に記している。注 14) ここ ではまず柱高さ（H of column）から柱下部径（D of column (base)）が 規定され、これがモデュール（第 1 位基準寸法注 ${ }^{15}$ ) として指定され ている (図 1)。さらに後述される梁上端幅 (W of epistyle (top)) も同 寸として並列的に扱われていることがわかる。このモデュールによ り 10 項目が規定される。その内、4 項目は、柱下部径付近の柱礎に 関わる部位であり、残りの 6 項目は、梁上端幅付近に位置する梁と 柱頭の外形寸法に関わるものである。

モデュールにて規定された 10 項目の内、四角い礎盤を除いた柱礎 高さ ( $\mathrm{H}$ of column base excl. plinth)、アバクスを含む柱頭高さ (H of capital incl. abacus)、そして梁高さ（H of epistyle）寸法が、新たな基 準寸法（第 2 位基準寸法）となり、個別に更なる部位を規定していく。 四角い礎盤を除いた柱礎の高さは 7 等分され、これが構成する $3 つ$ の部位にあてがわれる。アバクスを含む柱頭高さは、アバクス高さ $(\mathrm{H}$ of abacus）、渦巻き高さ（H of volute）など、イオニア柱頭を構成する 主要部分の寸法や位置を規定している。梁高さは梁を構成する部分 及び、梁の上に載るフリーズの外形寸法を規定している。

さらにアバクスを含む柱頭高さから規定された渦巻き高さは、渦巻 きの細部寸法と柱頭の装飾部位であるキューマティウムを規定する 第 3 位基準寸法の役割を果たす。同様に梁高さから導かれたキュー マティウム部位を除いた高さが第 3 位基準寸法となり、梁より上に ある部材の細部寸法を規定している。

以上、各項目の規定関係から再び全体を俯瞰してイオニア式のシュ ムメトリアの技法を要約すると、まず柱の下部径と梁の上端幅を同 寸とし、神殿の下部と上部にモデュールを配していることが注目さ れる。2 ケ所に配されたのは、おそらく前者が柱礎周りを規定するた めに、後者が神殿上部の部材群を規定するためであったと考えられ る。注 16 ) 第 1 位基準寸法から規定された寸法はどれも、神殿を構成す る主要部材の外形寸法か第 1 位基準寸法の直近に位置する部位に限 られている。そしてこれらの主要部材の中から再び重要な寸法が選 定され、その部位の周辺に位置する細部の寸法などが規定されてい く。この流れが繰り返され、複数の基準寸法が段階的に枝分かれし ていく形で、大きな部材からより小さな部材の寸法規定が行われて いくのがイオニア式のシュムメトリアの特徴である。

\section{2. -2. ドリス式のシュムメトリア}

ウィトルーウィウスは、第 3 書において神殿建築一般の平面形式 とイオニア式の神殿のシュムメトリアを説明した後、わざわざ書を 改めてそれ以外の様式のシュムメトリアを説明している。第 4 書で は、まず後述するコリント式柱頭のシュムメトリアが簡潔に述べら れ、続いてドリス式神殿のシュムメトリアが詳述される（第 4 書第 3 章第 $1 \sim 10$ 節)。ドリス式の規定項目の説明の流れは、おおむ敉 イオニア式と一緒で、まず神殿の外形寸法からモデュールを算出し、 それを用いて神殿の下から上へ向かって部位を規定している。ドリ ス式では、モデュールが正面ポルティコ幅から算出された後、それ
Doric Order (Diastyle): Vitruvius, De Architectura, Book IV, 3.1-10.

\begin{tabular}{ll|l}
4 columned portico $\frac{1 / 27}{(0.37)}$ \\
Diminution of columned portico $\frac{1 / 42}{(0.024)}$ same as Ionic system
\end{tabular}

Fig. 2 Diagram of the module system of the Doric temple as described by Vitruvius (Book IV, 3.1-10)

が柱頭高さ (H of capital)、平縁を含めた梁の高さ (H of epistyle incl. taenia and guttae)、そしてトリグリフの幅（W of triglyph）として指定 される。イオニア式と異なり、柱の下部径は 2 モデュールに指定さ れていることが注意を惹く。注 17)

寸法系統図（図 2）から分かるように、ドリス式は、単一のモデュー ルが全ての部位 (計 19 項目) を規定する技法である。単一系モデュー ル・システムであるため、寸法指定に使われる数值のヴァリエーショ ンは少なく、また同寸となる部位の多さが顕著である。また、イオ ニア式と比べて明らかに規定項目が少なくなっており、これは、単 に柱径の旡減や胴張りのつけ方、テュンパヌム、シーマ、コローナ などの屋根部分に共通する要素において「イオニア式に倣う」とい う略式記述（第 4 書第 3 章第 $4 ， 6 ， 10$ 節）があるだけではなく、ド リス式の特徵である柱礎の欠如や装飾要素の簡素さが設計技法に如 実に表れた結果であるとみてよいだろう。

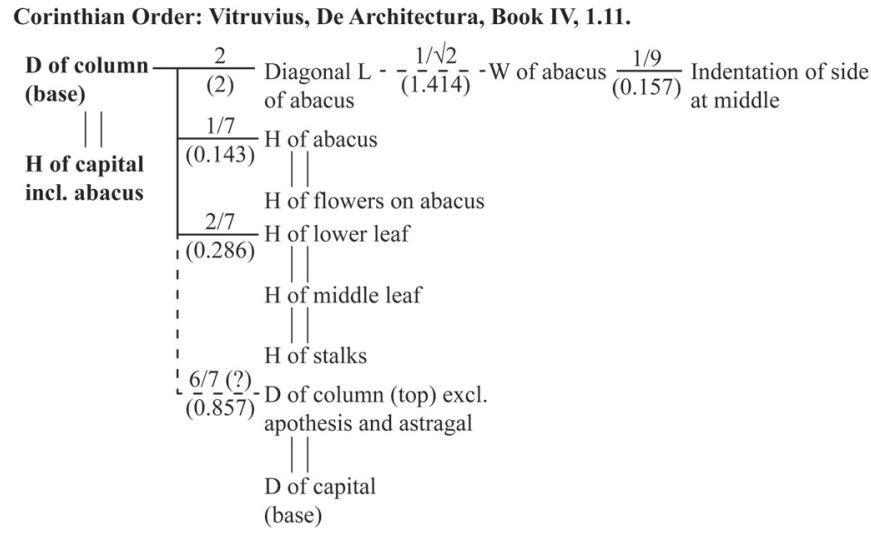

Fig. 3 Diagram of the module system of the Corinthian temple as described by Vitruvius (Book IV, 1.11) 
Tuscan Order: Vitruvius, De Architectura, Book IV, 7.1-5.

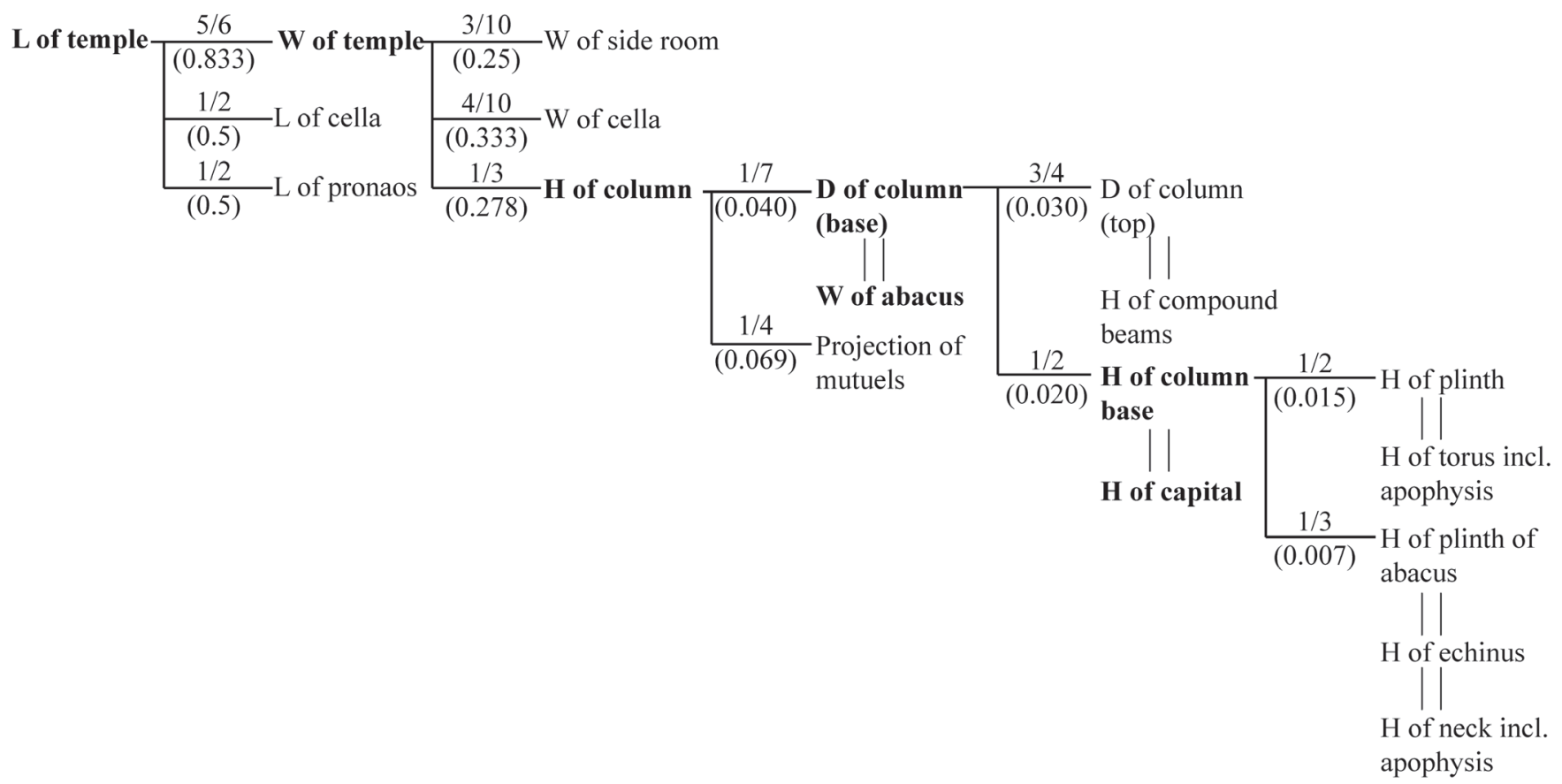

Fig. 4 Diagram of the module system of the Tuscan temple as described by Vitruvius (Book IV, 7.1-5)

\section{2. -3.コリント式とトゥスキア式のシュムメトリア}

イオニア式とドリス式以外のオーダーのシュムメトリアに関する 記述は限定的であり、これらはイオニア式に依拠している。コリン ト式神殿のシュムメトリアは、第 4 書においてドリス式より先に説 明されるが、「柱頭を除いてはすべてイオーニア式の柱と同じシュム メトリアを採る (第 4 書第 1 章第 1 節)」と明言されており、「クッショ ン (pulvinatus)」に喻えられる横長のイオニア式柱頭と異なる柱頭の シュムメトリアだけが説明されている。

柱頭の規定（図 3）をみると、その流れもイオニア式に準じ、アバ クスを含む柱頭高さがモデュールとして指定され、柱頭の細部を連 鎖的に規定している。ここで注目すべきは、アバクスを含む柱頭高 さを第 1 位基準寸法である柱の下部径と同列に扱うことで、神殿下 部から出発したモデュール寸法を梁上端幅同様に神殿上部に移して いることである。また、イオニア式（図 1) においても、アバクスを 含む柱頭高さが基準寸法として柱頭の各部位の寸法を規定している ので、コリント式の規定は、神殿の他の部位の比例体系に影響を与 えることなく、そのままイオニア式の柱頭の規定部分と差し替える ことができる。すなわち、両者における差異は数值のみということ になる。さらに、コリント柱頭のシュムメトリアでは、 $\sqrt{2}$ という無 理数の存在を念頭に置いた規定もあり、幾何学的作図の結果を数值 に置き換えた痕跡が看取される。注18)

その他には、アッティカ式とトゥスキア式に関する規定が断片的 に存在する。アッティカ人はイオニア人の一部族とされ、文化的に 同類視されるため、アッティカ式は、イオニア式の細部のヴァリエー ションと位置付けられ、「建築十書」では、基壇の細部意匠の差異が イオニア式神殿のモデュールの説明の中に挿入されている（第 3 書 第 5 章第 $2 \sim 3$ 節)。一方で、戸口の規定では、「ドーリス式と同じ 割り付けでつくられる（第 4 書第 6 章第 6 節)」との指示があり、こ の様式の混種性が窺われる。

トゥスキア式は、イタリア植民地の様式という意味において、ギ
リシア本土の様式とは地域的に異なる。このため、平面に関わる最 初の規定項目が差異として詳述されている。注 19)この様式はドリス式 に柱礎を足したものと解されるが、その発生が後発であるため、イ オニア式に倣ったモデュールの技法が踏襲されている（図 4)。この 様式でも柱下部径とアバクス幅という神殿の上・下部にあたる主要 部位がモデュールとされた後、柱上部径 (D of column (top))、柱礎高 さ ( H of column base)、柱頭高さ ( H of capital) などが規定され、これ らの第 2 位基準寸法がそれぞれに付属する部位を規定している。ド リス式と同じく装飾が簡素であるため規定項目は少ないが、設計方 法はイオニア式に準じているといって良い。

\section{3. エジプトの設計図にみられるモデュール理論}

古代地中海文明圈にいち早く栄華を極めていたエジプト文明から 出土している建築関連資料に目を向けると、まず人体図を描く技法 として、遅くとも紀元前 2000 年ごろ（中王国時代初期）にはグリッ ドを用いた描画方法が確立されていたことが了解される。注20) 前 750 〜 650 年頃（第 25 王朝）を境に人体像のプロポーションに変革が 訪れるが、グリッドを用いた人体形状の統御技法そのものは踏襲さ れつづけた。また同様の技法が立体表現でも用いられていたことは、 わずかではあるが未完成彫像の例からも明らかである。注21)

3 次元の物体の形状をグリッドを用いて定義するということは、す なわち直方体のような直行する面と面の関係を持つ形から削りだし ていく事を意味しており、平面形状と全体高さを規定した後、外観 を調整するには正面図と側面図が最低限必要になる。彫像の制作の 準備段階として、絵付師が、標準的な描画例で見ることができる人 体図注 22) ではなく、図面としての正・側面図を作成していたであろう ことは、未完成彫刻やパピルスに描かれた図面のセット（図 5 ～6) が出土していることから疑う余地はない。

プトレマイオス朝時代の制作と考えられるスフィンクスの彫像の 図面セット（図 5）では、彫像を構成する人間の頭部、ライオンの 


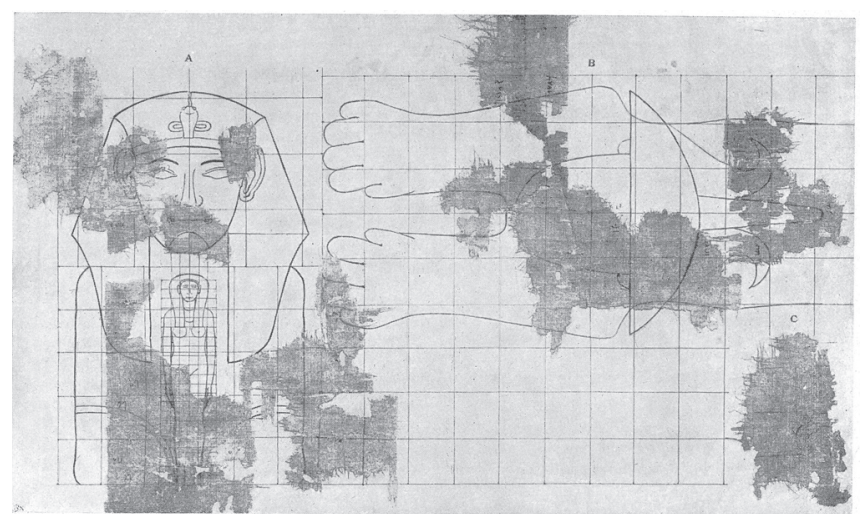

Fig. 5 Papyrus Drawings of a Statue of a Sphin $x^{22)}$

胴体部、そして守護される小像（女王?）のそれぞれに異なる大き さのグリッドが使い分けられていることが注目に值する。注23)この 3 種類のグリッドは、換算が可能となっており、いわゆる複数系のモ デュール・システムとみなせる。ハインリッヒ・シェーファーがす でに指摘したように、エジプト美術は各要素を統御するグリッドを 合わせることで、複合的な彫刻作品を実現しているのである。注24)

またアコリス近郊のプトレマイオス朝時代の石切り場に残された 未完成巨像などでは、描画における肩幅や手幅などを正面から表現 した立像図ではなく、まさに掘り出すための側面図が描かれている ことも注目される。注25)ここでは、グリッドを描くことを割愛し、よ
り簡略化された垂直軸のガイドラインを 2 本引いて、ファラオの側 面図が作図されている点が重要である。また、この技法がおそらく 新王国時代までには開発されていたであろうことは、近年発見され た絵付師の描画の習作として描かれたファラオの正面図注26)や、彫像 に残されたグリッドの痕跡などからも窺うことができる。

狭義の意味での建築注 27)に目をむけると、エジプトの祠堂の設計図 にみられる特徵として、グリッドを用いた方法、数字でモデュール を描いた例などが知られている。注28) 前者の例にあたる「グラーブ祠 堂パピルス」（図 5) に描かれた木製祠堂のプロポーションを分析寸 ると図 6 のようになる。

グリッドの 1 マス分が、柱太さ (W of jamb)、楣厚さ (Th of lintel)、土台高さ (H of podium)、天蓋の屋根曲線の高低差（H of curved roof of canopy）に充てられ、モデュールの役割を果たしている。 他の主要な部位はマスの整数倍と主に $2 / 3$ と $5 / 6$ を含む単位分数を用 いて規定されたとみられ、グリッドという単一系モデュールから導 かれた設計技法であるとみな寸ことができ、ドリス式の寸法体系と 同じ技法であるとみなせる（図 7)。

ローマ時代のパピルスでは、グリッドを用いる代わりに数值で主 要部位の比例が明示されており、先述の祠堂の立面図とは一見異な る方法で寸法が規定されているようにみえる。注299しかし、ここで使 われている数值は前例のグリッドを単位とした寸法值と一致し、ど ちらも柱太さと相厚さを基準としたモデュール・システムであると
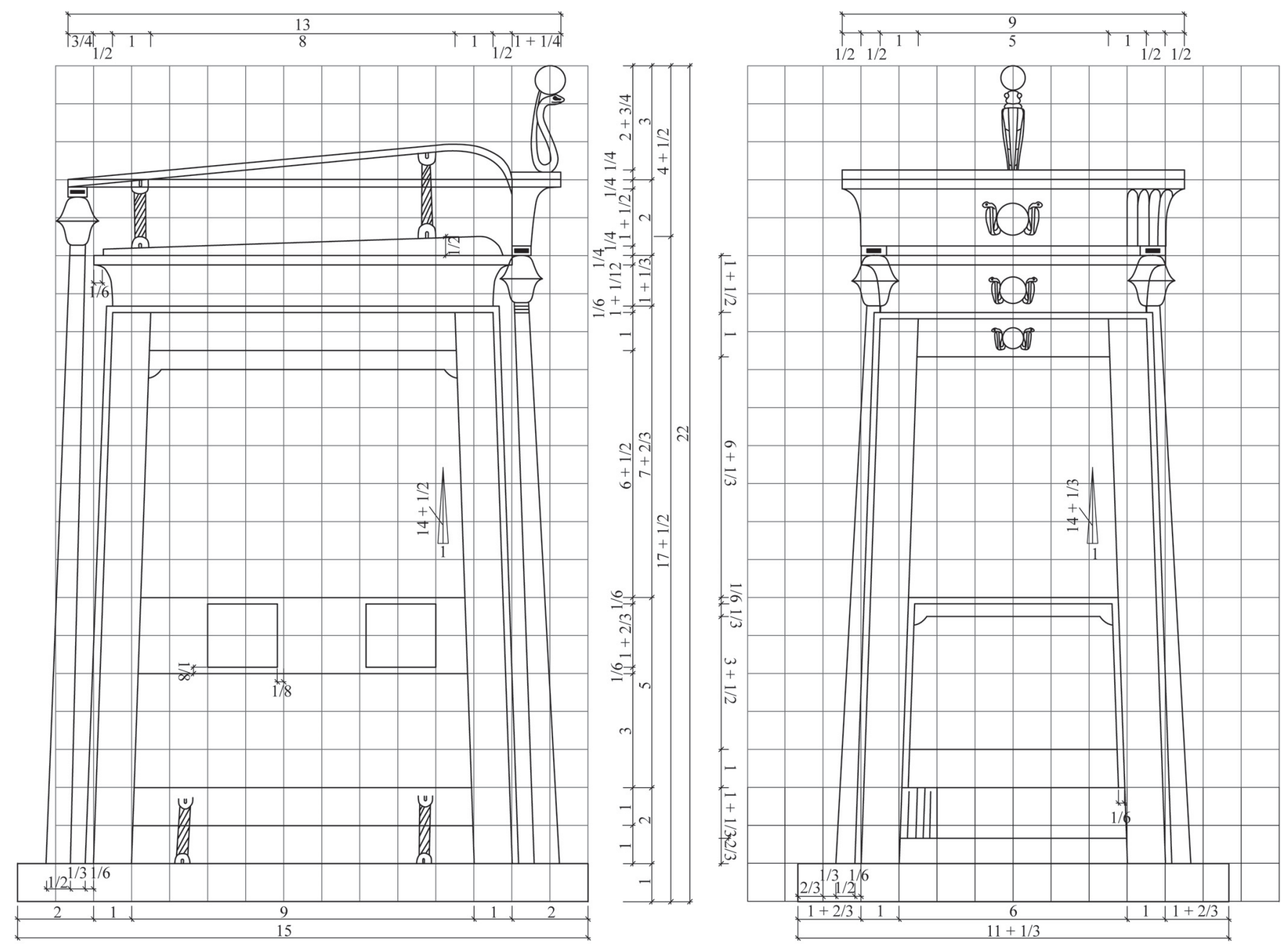

Fig. 6 Diagram of the module system of the Egyptian naos-shrine from the "Ghurob Shrine Papyrus" 
Module System of the "Ghurob Shrine Papyrus" (reconstructed from the front view)

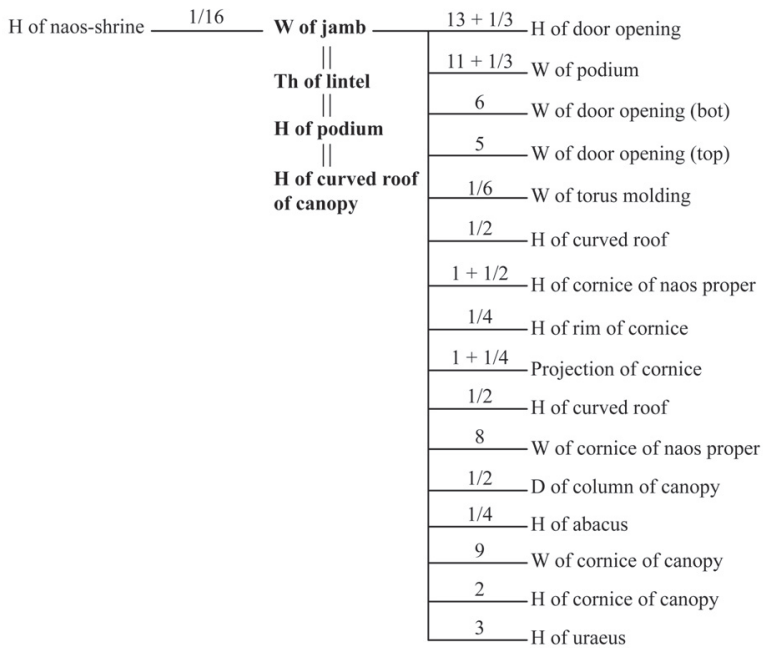

Fig. 7 Diagram of the module system of the Corinthian temple as described by Vitruvius (Book IV, 1.11)

いえる。このパピルスでは、高さにおける全高 $(17+1 / 2)$ と部分高 さの合計 $(17+1 / 12)$ が一致しないという現象がみられるが、これは、 外形計画を行った後に細部を調整したことに起因すると著者は考え る。なおこれらの例は、いずれもギリシア・ローマ時代の設計図で、 エジプト建築設計においてモデュールの技法が伝統的に用いられて いた直接的証拠にはならない。しかし、祠堂や祠堂型家具のプロポー ションの分析では、第 18 王朝時代までの作品でその使用が確認され ており、人体形状をグリッドを用いて制御する方法が中王国時代ま で遡ることを考慮しても、建築におけるモデュールの技法が少なく とも新王国時代に遡るとみてもよいだろう。注30)

その他、柱に関しては設計図は残っていないが、施工図や模型が 残っている。これらの資料の多くは、発見後に分析が行われてこな かったため詳細は未だ不明であるが、シストラム柱頭はグリッドを 用いて設計され、植物型柱頭は、グリッドを用いない方法で設計さ れていたことが判っている。注31) また両種類の柱頭も、柱頭のみが描 かれる例が大半を占め、柱身および建物全体との寸法上の関連性は 不明な点が多い。唯一、柱全体が描かれた施工図を1896 年にルート ヴィッヒ・ボルヒャルトが報告しており、彼によれば、柱頭の割り 付けと柱身との関係性がイオニア式に代表される系統と同じような モデュールの技法で計画されていたようである。注32) すなわち、柱 頭の施工図はイオニア式と同様の複数の基準寸法を用いた寸法体系 の中の一部分を抽出したものである、と考えることができるのであ る。

\section{4. 比較考察}

以上、ウィトルーウィウスの「建築十書」で述べられた 4 つ様 式（イオニア、コリント、ドリス、トゥスキア）と古代エジプトか ら出土しているファラオ様式の設計図・施工図に見られるモデュー ルの技法を分析した。まず注目されるべきは、エジプトの設計図や 施工図にみられるモデュールの技法とヘレニズム文化のシュムメト リアにみられる技法に本質的な違いはなく、地中海文明圈を一つと して考ることができるということである。数字の使い方に関してい えば、地中海の南北に関わらず、以下の方法が認められる。
1) $\mathrm{M} \times 1 / \mathrm{n}(=\mathrm{M} / \mathrm{n}), \mathrm{n}$ : 自然数

2) $M+1 / n(=M \times(n+1) / n), n$ : 自然数

3) $M-1 / n(=M \times(n-1) / n), n$ : 自然数

4) $M / n \times n_{1}\left(=M \times n_{1} / n\right), n=n_{1}+n_{2}+\ldots .+n_{a}, n$ : 自然数

これらの数字の用法は、エジプト、ギリシア、ローマに共通するも のであり、数学書などを紐解いても同傾向がみられることが知られ

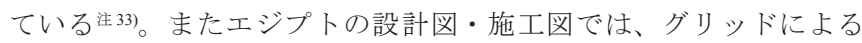
描画と数值表記による作図方法の 2 種類がみられるが、双方ともモ デュールの技法が通底している点において変わりはない。注34)この他 にも、共通する事項としては、高さと出／幅の比が 1:1になる、いわ ゆる「胴返し」の技法や、ある部位を等分してさらに細かい部位に 充てる分割の技法などが挙げられる。

次に、これらの技法は、大きく 2 系統に別れることが注意を惹く。 一つはドリス式とエジプトの祠堂の立面図にみられる単一モデュー ルを用いた技法、そしてもう一つはイオニア式とそれに準拠するコ リント式、トゥスキア式、およびエジプトの柱の施工図が示す複数 の基準寸法を連鎖式に用いる方法である。

クールトンはウィトルーウィウスのシュムメトリアの記述の分析 において、ドリス式とイオニア式の違いを重要視し、前者をモデュー ルの技法、後者を「連続方式（successive system）」と呼び区別してい る一方で、実際はドリス式にもイオニア式の設計技法が用いられて いたとみている。注 35) 事実、当時の建築家たちが孤立するドリス式の 設計技法をイオニア式系統に編集し、統一化を図ることは容易にで きたであろうが、前 20 年頃のローマ人建築家ウィトルーウィウスは、 シュムメトリアの技法に関する先人たちの覚書を紐解き（第 7 書序 章第 $11 \sim 14$ 節)、敢て歴史的に正しいと考えられる「古式」を採用 した。すなわち、両者の設計技術上の差異は、時間軸において並列 的ではなく直列的発展に起因寸ると考えるべきである。

イオニア式に代表される複数系モデュール・システムが、単一系 モデュール・システムから派生した技法であることを示す点がいく つかある。まず、どちらのシステムも柱下部径と梁/楣厚さをモデュー ルとして、あらゆる部分を規定していることにある。この 2 つの寸 法が基準寸法として選ばれるのはイオニア式、ドリス式そしてエジ プトの祠堂の設計図における共通事項であることからも、地中海文 明圈の両者の寸法が建築設計上の共通認識であったと考えられる。 さらにこの両部位に準じて重要な寸法と考えられていたのは柱頭高 さ ( H of capital) と柱礎の厚さ ( H of column base) である。柱頭高さは、 ドリス式およびュリント式ではモデュールとみなされ、イオニア式 およびトゥスキア式ではモデュールの $1 / 2$ として第 2 位基準寸法の役 割を果たしている。柱礎の厚さはイオニア式、トゥスキア式では同 じくモデュールの 1/2 であり、コリント式もイオニア式に準じるため 同量である。すなわち、全ての様式に共通する重要な寸法はモデュー ルと同寸であるか $1 / 2$ か 2 倍の関係にあり、イオニア式系統は、ドリ ス式およびエジプトの祠堂の系統で用いられたモデュールとしての 基準寸法を、適宜、第 2 位基準寸法へとずらしたものとみなすこと ができるのである。

ここで特筆に值するのはドリス式におけるモデュール、且つイオ ニア式では第 2 位基準寸法となる共通部位を、柱の上・下端に配置 している点である。基準寸法を建物の上下に配置するということは、 
すなわち、下部で柱太さの基準寸法を取り巻く部位がこれによって 規定され、上部は、梁／楣の寸法を基準としてその周囲の寸法が規 定されることを意味する。

このように、両系統には同一の設計思想が通底していると見る心゙ きである。これは、様式上観点からも、装飾的に簡素なドリス様式 からやや遅れて植物型柱を用い、装飾も多く備え、より洗練された イオニア様式が発生したように、それぞれの時代で主流であったモ デュールの技法が採用されたことに起因すると考えられる。この考 え方を敷衍すれば、様式的にはドリス式に柱礎を加えたトゥスキア 式が、時代的にイオニア式系統の設計技法に位置づけられることも 納得できる。

では、なぜ派生が生じるようになったのであろうか。単一系モ デュール・システムの短所とは、そして複数系モデュール・システ ムを考案する希求とは如何なるものであったか。

ドリス式は、モデュールから規定されるあらゆる部位の寸法を大 小関係なく同等に扱うものであり、部位同士の関連性は存在しない。 また基準寸法が一つしかないため、設計者は特定の部位を変形させ る場合、自ら系統図の中から関連する寸法を探し出しモデュールに 対する数值を個別に変える必要がある。部材の規定数が比較的少な いドリス式では問題にならないが、規定項目が多くなればなるほど、 特定の部材を抽出して数値変更を施す作業は困難になっていく。ま たドリス式では最小值が 1/12 となり、それ以下の寸法值の指定は、 現実的ではなかっただろう。通常、柱下部径がモデュールとされる にもかかわらず、この部位を 2 として、その半分にあたる部材をモ デュールに設定しているのも、1/24 という、施工において骨の折れ る細かい分割作業を避けるためであったと考えられる。注36)

これに対してイオニア式は、部位ごとに規定項目が整頓されてい て、それを統括する大きな寸法が基準寸法となり、別の部位の基準 寸法と関連付けられる。そして一旦基準寸法が変更されると、連動 し且つ一定の比例関係を保ちつつセットとなっている部分の形状だ けの大きさが変えられるという、所謂「部分編集機能」が付いたよ うなものと考えてよい。またイオニア式系統の場合、第 3 位以下の 基準寸法は第 1 位基準寸法に遡って計算されることはなく、あくま でも、直上の基準寸法から簡単な分数にて導かれることが重要であ る。イオニア式系統は基準寸法となる部位から最小で $1 / 12$ 分割をと ることはドリス式系統と同じだが、ドリス式系統とは対照的に、こ れを繰り返し行うことで最小の部分で最初のモデュールの $1 / 84$ の寸 法を実現している。イオニア式系統のシュムメトリアの技法が、そ の細部の微妙な寸法までを規定することを可能としている点こそが ウィトルーウィウスをして「最も精緻な (subtilissimus)」様式と位置 づけさせている所以であろう。注37) また、基準寸法に関しても複数の 階位を設けているため、第 1 位基準寸法は神殿の上下にそれぞれ 1 力 所ずつ設定するだけで、残りは連鎖的に細部まで規定されていく。 逆に言えば、ドリス式はイオニア式で第 2 位、第 3 位基準寸法となっ ている部位を全て第 1 位基準寸法にしてしまうことで、他の部位を 並列的に扱い、簡潔な寸法体系を保持している。建築において装飾 に価值を見出し、それが複雑化していった後世の時代において、イ オニア式のシュムメトリアが他の様式に採用されたのは、上記の利 点による必然であったと考えられる。

しかし、複雑化した寸法体系を作り上げてまでシュムメトリアの
技法を用いて設計をする必要性はどこにあったのだろうか。森田が すでに指摘しているように注38)、シュムメトリアが「美の統一原理」 であったならば、一体、古代人にとって「建築美」とは何であったか。 ウィトルーウィウスにとって、神殿各式のシュムメトリアとは「外 観（exterior）」（第 4 書第 3 章第 10 節）に関するものであり、「美の 理は、実に、建物の外観が快く典雅であり、肢体の寸法関係が正し いシュムメトリアの理論をもっている場合に保たれるであろう」(第 1 書第 3 章第 2 節 ) とされた。また「シュムメトリアについて加減が 行なわれるにしても、建物が正しい形になっていると見え、外観に ついても何ら不満がないように」(第 6 書第 2 章第 1 節)、とあくま でも外観を統御することに重点を置いていることは、強調されてし かるべきである。

この意味において、建築遺構の平面計画の復元研究においてモ デュール理論やグリッドをあてはめる研究は排除されるべきである。 注39) 概して、神殿の平面計画において柱の本数や神殿の形式とファ サードに関連する部分は言及されるが、全体の縦横比、壁厚と部屋 の外形寸法との関係、側面の奥行、柱の本数、柱下部径と柱間の関 係などがどうあるべきかについては一切記述がない。

一般に、古代地中海文明の神殿建築の計画の手順として、敷地の 選定 $\Rightarrow$ 平面の規模と形式の決定 $\Rightarrow$ 立面（特に正面ファサード）の計 画 $\Rightarrow$ 細部の計画、という順序が想定されるが、シュムメトリアの技 法の本質はモデュールを使って、立面の各部位の寸法を統御するこ とにあり、寸法系統図の中で、モデュールを定めるまでの神殿平面 と全体高さの寸法計画はシュムメトリアの技法の前提部とみるべき である。

平面計画から立面計画に移行する段階でのモデュールの技法の導 入は、すなわち、シュムメトリアの技法の主眼が、あくまで人間の 眼に自然に感知できる比例関係（特定部位の幅と高さの比、連続す る高さ寸法の比）の見栄えをうまく制御することにあることを意味 している。それは、平面における幅と奥行きの単純な比例や、建物 を斜めから見た時の側面の見え方などのことではなく、ファサード の立面に他ならない。そしてこれはエジプトの設計図にみられるモ デュールの技法が立面を主に統御するために、グリッドや数值を割 り振っていることと同じであるとみなせる。

また、このシュムメトリアで定められた数值は、計画の最終段階 では、「エウリュトミア (eurythmia)」あるいは今日「リファインメ ント」とよばれる視覚補正の技法によって予断無く変更され、柱の 転びやエンタシス、基壇のむくりなどによって、シュムメトリアに よって定められた、一見厳格に見える数值はいとも容易く失われる のである。すなわち、古代人にとってシュムメトリアは、数值の正 確さが重要なのではなく、リファインメントの御膳立てとして、外 観を簡潔な比例関係によって整える技法であり、その後、リファイ ンメントによって数字にとらわれぬ最終調整によって建物の見栄え を完成形たらしめるものであった。

このように、古代地中海文明圈におけるモデュールを用いた設計 技法は、今日の研究者が見出そうとしている、平面図上の「幾何学 的美」のような、実際の建物を目の前にした人間が即座に享受でき ない比例関係には、意味を与えていなかったことが了解される。こ こに、今日我々の社会が重んじている空間性と比例を用いた設計理 論が果たすべき役割について決定的な価值観の違いがみられる。 


\section{5. まとめ}

本稿はウィトルーウィウスの「建築十書」にみられるシュムメト リアの技法とエジプトの設計図・施工図からみられるモデュール理 論を比較検討し、古代地中海文明圈における設計技法の共通点と相 違点を明らかにした。そこから得られた新たな知見を以下にまとめ る。

ドリス式とイオニア式及びその他の様式の間には、これまで柱礎 の有無、植物柱頭のモチーフの有無、そして梁より上の部分の装飾 モチーフの明白な違いが指摘されてきた。本稿では、これと同様の 違いが、設計技法上にもみられることを明らかにした。両者の違いは、 より古式であるドリス式の設計思想に手を加えたイオニア式の設計 技法が生まれたことを示している。

近年、シュムメトリアの技法を含む、ウィトルーウィウスの「建 築十書」に示されている基本的な建築観がより古い時代のエジプト にもみられ、これらの起源がエジプトに遡る可能性が示唆された。 寸なわち、今日我々は、ウィトルーウィウスの「建築十書」を古代 地中海文明が建築理論において紀元前 1 世紀後半ごろに到達した点 として捉えなおす必要があり、より詳細な比較分析を要する。

ウィトルーウィウスはあくまでも、シュムメトリアを用いて設計 された建築が美しい、と述べているのであり、シュムメトリアの技 法が美しいのではない。既往研究が、ギリシア哲学者を引用してシュ ムメトリアの概念や技法そのものに美を見出そうとしたり、数值関 係を吟味して「絶対的に美しい数值」なるものを見出そうとしたり することは、根本的に古代の建築思想と外れているといわ秝ばなら ない。

なお本研究は、他の設計技法が存在した可能性を否定するもので はない。しかし、西洋建築文化のモデュール理論がギリシアではなく、 元来地中海文明圈のより古いエジプト文明にすでにみられるという ことは強調しておくべきと考える。

\section{謝辞}

本研究は、日本学術振興会特別研究員奨励費（16J07906）および 科学研究費補助金若手研究 (A)（17H04947）の助成によって行われた。 また、本稿の執筆にあたり、東京大学建築学科歴史系研究室のメン バー、加えて木谷建太氏（早稲田大学）、西本真一氏（日本工業大学）、 米澤貴紀氏（名城大学）との議論を通して有益な知見が得られたこ とを末筆ながら記し、御礼申し上げる。

\section{参考文献}

1) Morita, K.: Vitruvius. De Architectura, Tokai University Press, 1969 (in Japanese)

森田慶一 : ウイトルーウイウス建築書, 東海大学出版会, 1969

2) Fensterbusch, C.: Vitruv. Zehn Bücher über Architektur, Darmstadt, 1991

3) Motora, I.: Architectural Ideas of Ancient Greeks, Memoirs of the Osaka Institute of Technology, Series B: Liberal Arts and Social Sciences, Vol. 15, No. 1-2, pp. 11-43, 1970 (in Japanese) 元良勲: 古代ギリシアの建築思想, 大阪工業大学紀要人文社会篇, 第 15 巻, 第 1-2 号, pp. 11-43, 1970

4) Morita, K.: On Architecture, Tokai University Press, 1978 (in Japanese) 森田慶一: 建築論, 東海大学出版会, 1978

5) Yasuoka, Y: On the Relationship between the Architectural Philosophy in Vitruvius' "De Architectura" and the Surrounding Architectural Cultures: A comparative study of the Ancient Egyptian architectural media, Journal of Architectural Planning (Transactions of AIJ), Vol. 82, No. 736, pp. 1581-1589, 2017. 6 (in Japanese)

安岡義文: ウィトルーウイウスの「建築十書」の記述にみられる建築思想と周辺建 築文化との関連性について, 古代エジプトの建築関連資料との比較分析を中心 に, 日本建築学会計画系論文集, 第 82 巻, 第 736 号, pp. 1581-1589, 2017. 6

6) Richter, J. P.: The Notebooks of Leonardo Da Vinci. Compiled and edited from the Original Manuscripts, Vol. 1, New York, 1970

7) Marani, P. C.: Leonardo, The Vitruvian Man, and the De statua Treatise, Radke, G. M. (Ed.): Leonardo da Vinci and the Art of Sculpture, New Haven, pp. 82-93, 2009

8) Hinz, B. (Ed.), Albrecht Dürer: Vier Bücher von menschlicher Proportion (1528), Altenburg, 2011

9) Le Corbusier: Le Modulor, Vol. 1, Boulogne, 1950

10) Le Corbusier: Le Modulor, Vol. 2, Boulogne, 1955

11) Payne, A. A.: The Architectural Treatise in the Italian Renaissance: Architectural Invention, Ornament, and Literary Culture, Cambridge, 1999

12) Jones, M. W.: Principles of Roman Architecture, Singapore, 2000

13) Hambidge, J. (Ed.): The Parthenon and other Greek Temples: Their Dynamic Symmetry, New Haven, 1924

14) Mössel, E.: Vom Geheimnis der Form und der Urform des Seins, Stuttgart 1938

15) Ito, J.: The Site Planning of Greece and Rome: Theory and Practice of Architectural Planning in the Sanctuaries of Classical Antiquity, Kumamoto, 1988

16) Coulton, J. J.: Towards Understanding Greek Temple Design: General Considerations, Annual of the British School at Athens, Vol. 70, pp. 5999, 1975

17) Stewart, A. F.: The Canon of Polykleitos: A Question of Evidence, The Journal of Hellenic Studies, Vol. 98, pp. 122-131, 1978

18) Heisel, J. P.: Antike Bauzeichnungen, Darmstadt, 1993

19) Ito, J.: Ancient Greek Architectural Drawings, Journal of Architecture, Planning and Environmental Engineering (Transactions of AIJ), Vol. 57, No. 435, pp. 109-118, 1992.5 (in Japanese) 伊藤重剛：古代ギリシアの建築設計図，日本建築学会計画系論文報告集，第 57 巻, 第 435 号, pp.109-118, 1992.5

20) Robins, G.: Proportion and Style in Ancient Egyptian Art, London, 1994

21) Yasuoka, Y. and Nishimoto, S.: Proportional Analysis of a Colossus of Zawiyat Sultan in Egypt, Summaries of Technical Papers of Annual Meeting, Architectural Institute of Japan, F-2, History and Theory of Architecture, pp. 695-696, 2016 (in Japanese)

安岡義文, 西本真一: エジプト・ザーウィヤト・スルターンの巨像のプロポーショ ンについて, 日本建築学会大会学術講演梗概集, F-2, pp. 695-696, 2016

22) Borchardt, L.: "Sphinxzeichnung eines ägyptischen Bildhauers", Amtliche Berichte aus den Königlichen Kunstsammlungen, Vol. 39-5, pp. 105-110, 1917-1918

23) Schäfer, H., Brunner-Traut, E., Baines, J.: Principles of Egyptian art, Oxford, 1986

24) Endo, T.: Architectural Study on the Relationship beween Red Lines and Graffiti found at the Underground Chambers of Unifnished Colossus, Cyber University Bulletin 1, pp. 33-51, 2009 (in Japanese) 遠藤孝治: 未完成巨像の地下で発見された文字と赤線に関する建築学的考察, サイバー大学紀要, 第 1 巻, pp. 33-51, 2009

25) Galán, J.: An Apprentice's Board from Dra Abu El-Naga, in: Journal of Egyptian Archaeology, Vol.93, pp. 95-116, 2007

26) Yasuoka, Y.: A Reassessment of the "Ghurob Shrine Papyrus", Oriento, Vol. 58, pp. 156-169, 2015 (in Japanese) 安岡義文:『グラーブ祠堂パピルス』の再評価, オリエント, 第 58 巻, pp. 156169, 2015

27) Tait, J. W.: A Papyrus bearing a Shrine Plan and a Book of the Dead, in Hoffmann, F. and Thissen, H.-J. (Eds.): Res Severa Verum Gaudium. Festschrift für Karl-Theodor Zauzich zum 65. Geburtstag am 8. Juni 2004, Leuven, pp. 573-582, 2004

28) Yasuoka, Y.: The Use of Module System in Ancient Egyptian Architecture, Orient, Vol. 53, pp. 5-24, 2018

29) Yasuoka, Y.: Untersuchungen zu den Altägyptischen Säulen als Spiegel der Architekturphilosophie der Ägypter, Hützel, 2016 
30) Borchardt, L.: Altägyptische Werkzeichnungen, Zeitschrift für Ägyptische Sprache und Altertumskunde, Vol. 34, pp. 69-76, 1896

31) Imhausen, A.: Mathematics in Ancient Egypt: A Contextual History, Princeton and Oxford, 2016

32) Hiller, F.: Maß und Freiheit - Anthropometrie in der griechischrömischen Antike, Branfels-Esche, S. (Ed.), Der »vermessene« Mensch: Anthropometrie in Kunst und Wissenschaft, München, pp. 32-41, 1973

33) Morita, K.: Symmetria in the Classical Architecture, Murata, K. (Ed.), On Greek Art, pp. 27-47, 1944 (in Japanese)

森田慶一：古典建築に於けるシュムメリア, 村田潔編, ギリシヤ藝術試論, 東 京出版 , pp. 27-47, 1944

34) Morita, K.: Studies on Vitruvius, Shokokusha, 1957 (in Japanese) 森田慶一: ウイトルウイウス研究, 彰国社, 1957 年

35) Arnold, D.: The Encyclopedia of Ancient Egyptian Architecture. London/ New York, 2003

36) Bianco, G.: Two Different Building Modules of Measurement at Kommos - A Neopalatial Module in Building T and a Postpalatial Module in Building P, Foster, K. P. and Laffineur, R. (Eds.), Metron: Measuring the Aegean Bronze Age, Eupen, pp. 415-420, 2003

37) Riemann, H.: Hauptphasen in der Plangestaltung des dorischen Peripteraltempels, Mylonas, G.E. (Ed.), Studies presented to David Moore Robinson on his Seventieth Birthday, Vol. 1, St. Louis, pp. 295308,1951

\section{注}

注 1) 本稿では「建築十書」の邦訳にあたり、文献 1 を引用した。なお、「建築 十書」の原語表記の確認は文献 2 を用い、英字表記の内、大文字をギリシア語、 イタリック体をラテン語に用いた。

注 2)この語は一般に「均斉」と訳され、ラテン語でいう「commensurationis」、 現代語において数学などの専門用語を借りて、「通約性」(文献 3 参照)、「共 約性」(文献 4 参照) といった訳にあたる。しかし、建築学的には「寸法の統御」 あるいは「寸法体系」と訳すのが妥当かと思われる。また、ウィトルーウィ ウスの「建築十書」の内容がギリシア語文献を参考にして描かれたものであ り、この技法をすでにギリシア人たちが用いていたことは疑う余地はない(文 献 5 参照)。従って、本稿ではこれを前提としてギリシア建築を含めて議論 を進めていく。

注 3) 文献 $6 \sim 7$ 参照。

注 4) 文献 8 参照。

注 5) 文献 $9 \sim 10$ 参照。

注 6) ルネッサンス期に著された数多くの建築書については文献 11 を参照。

注 7）ルネッサンス期から現代までに至る連綿と続いてきたプロポーションの 研究に関しては文献 12 を参照。

注 8) 文献 $13 \sim 14$ 参照。

注 9) 代表的なものとして文献 15 を挙げておく。

注 10）文献 16 参照。なお、彫刻美術の比例に関する既往研究に対しても同様 の問題性が指摘されている。文献 17 参照。

注 11）また、当時の建築家は建物を設計する時に、地中海文明圈の各都市に散 らばった類例を訪れ、寸法体系を比較勉強することは困難であったと考えら れる。ウィトルーウィウスも右に同じく、書物から情報を集めていたと考え られる。

注 12 ) 文献 3 ; 文献 4, pp.165-167 参照。

注 13) 古代地中海文明圈の設計図に関しては、文献 $18 \sim 19$ を参照。ギリシア・ ローマ文明ではエジプト文明と比べて、設計技術を抽出できる史料が極めて 乏しいことが了解される。

注 14）古代地中海のマニュアル的性格を持つ文書（技術書、医学書、儀礼書など） において、事例を挙げていく場合、最も標準的となる形式をまず詳述し、以 後の事例では、最初の例と異なる部分だけを述べるという略述形式をとるの が一般的である。

注 15）本稿では、ウィトルーウィウスの文章を寸法系統図として「視営化」さ れる設計技法の構造的特質をより明確に理解するためにモデュールを第 1 位 基準寸法、モデュールにより規定された項目の内、他の寸法を規定するもの を第 2 位基淮寸法、第 2 位基準寸法ににより規定された項目の内、他の寸法 を規定するものを第 3 位基準寸法、というように便宜的に呼ぶ。ウィトルー ウィウスは、「モデュールとそれ以外の寸法」というドリス式の設計技法の 考え方に則った用語を用いており、イオニア式に代表される寸法群のヒエラ ルキー（階位および他の寸法を規定する役割の有無）を古代人がどのような 名称で呼び分けていたのかは不明である。
注 16) これがデザイン上だけでの役割を果たしていたのか、それとも施工にお いても作業手順を示寸ものとして用いられていたのかは不明である。

注 17）ドリス式では、大きめの部材も小さめの部材も単一モデュールによって 規定されるため、柱の下部径をイオニア式と同じように 1 とすると、小さな 部位がモデュールの $1 / 24$ といった細かい分数規定になってしまうため、実 用性を失うことが懸念された可能性がある。第 3 章では直系の $1: 6$ か $1: 7 、$ 第 5 章では半径の $1: 15$ と、場合によって、柱の直径か半径をモデュールと みなしている点は注意が必要である。

注 18)ここで注目すべきは、ウィトルーウィウスが $\sqrt{ } 2$ という無理数という 数としての概念を使わずに「(正方形における) 稜から稯一の対角線の長 さ (diagonia ab angulo ad angulum)」（第 4 書第 1 章第 11 節）と表現 していることである。またウィトルーウィウスは、第 6 書第 3 章第 3 節で も同長さを「その対角線が持つ長さ (quantum spatium habuerit ea linea diagonii)」(第 6 書第 3 章第 3 節）と呼んでいる。

注 19）トゥスキア式やドリス式では、モデュールである柱径が規定される神殿 の規模に関わる規定が述べられているのに対して、イオニア式にはこのシュ ムメトリアがないが、これはイオニア式の前提部分にあたる規定が、柱の本 数、柱径、柱間の様々な平面形式とともにすでに詳述されているためである。 注 20) 文献 20 参照。

注 21) 文献 21 参照。

注 22) エジプトの図像は複数の角度からみられる情報を一つの図に表現したも のとして理解される。

注 23) 文献 22 参照。

注 24）文献 23 参照。

注 25）文献 21、24 参照。

注 26) 文献 25 参照。

注 27）筆者は、古代において建築とは、彫像、絵画、構造物が一体化されたも のとして理解しているが、狭義の意味では彫像、絵画を排除した今日におけ る狭義の意味での建築として理解されたい。

注 28）図版に関しては、文献 $5 、 26$ 参照。本稿では、議論に関連する分析図の み掲載する。

注 29) 文献 27 参照。

注 30$)$ 文献 28 参照。

注 31）文献 29, pp.187-214 参照。

注 32 ) 文献 30 参照。

注 33）地中海北部ではパピルスにに描かれた設計図そのものが残っていないた め、エジプトのようにグリッドを補助として描画していたかどうかは確認で きない。

注 34) 文献 16, pp.74-79、文献 31 参照。

注 35) 文献 16. p.69 参照。

注 36）彫刻のような細部寸法に神経を使う作品においても、モデュールの $1 / 32$ が最小寸法であったとされている (文献 32 参照)。特に、ドリス式では、 柱下部径をモデュールとせず、柱下部径の $1 / 2$ の長さにあたる柱頭高さ、エ ピステューリウムの高さをモデュールとしているのが、不自然であり、本来 の考え方通りの順序で語られていない可能性が考えられる。注 16 参照。

注 37）ドーリア人、イオニア人、アイオリス人などの民族で構成された古代ギ リシアの都市国家においてイオニア式が代表格とみなされるのは、建築だけ ではなく一般的な見解であったようである。古代エジプトの文書ではギリシ ア人の総称を「ユーニー」と呼び、中世以降でも、アラビア語では今日でも ギリシア人を「ユナーニー」と呼び、これらの語がイオニアを外来語化した ものであることは明白である。

注 38 ) 文献 $33 \sim 34$ 参照。

注 39 ) 文献 $3, p$. 165 。文献 $35 \sim 37$ 参照。 


\section{ON THE MODULE SYSTEM OF THE ANCIENT MEDITERRANEAN CIVILIZATION}

A comparative analysis of the descriptions in Vitruvius' "De Architectura" and the Egyptian Architectural Media

\section{Yoshifumi YASUOKA*1}

${ }^{* 1}$ Superlative Postdoctoral Fellow of JSPS, Dept. of Architecture, Faculty of Engineering, The University of Tokyo, Dr.Phil.

The architectural treatise "De Architectura", written around 20 BC by Roman architect Marcus Vitruvius Pollio, is known to be the best-preserved example of writings on architectural theory in the Ancient Mediterranean civilization. The core elements of the Vitruvian design theory, which were the proportional method of design known as the "module system", and the analogy between architecture and human body, have influenced many architects and artists since the Renaissance Period, as seen in Leonardo Da Vinci’s "Vitruvian man", Albrecht Dürer's proportional studies, and Le Corbusier's concept of "modulor".

In contrast to the unequivocal significance of the Vitruvian treatise, the contents of his architectural theory has remained a subject of controversy. Due to the frequent usage of Greek words in Vitruvius' "De Architectura", it is generally accepted that most of his ideas were derived from Greek writings. However, this only sets the terminus ante quem. Taking Ancient Egypt - where Greek philosophers, mathematicians, astronomers, historians and other intellectuals have studied -into consideration, and conducting a comparative analysis with the Hellenistic design method shines new light upon the possible origins of the concept of the module system, which hitherto has been considered a Greek invention, and would enable us to re-unite the scattered fragments of Ancient Mediterranean architectural history.

Analyzing the Books III and IV of the Vitruvian treatise, a clear distinction between the module system of the Doric and Ionic style can be made. The Doric system uses a single module that defines all parts of a building. On the other hand, the Ionic system, which Vitruvius described as "the most sublime", builds a chain of modules. It starts from a single module, as the in the Doric system, but some of the dimensions defined by the first module become the secondary modules and define further sets of dimensions. This process repeats until all parts of a building are exhausted.

Concerning the technical drawings from Egypt, two examples of elevation drawings of an Egyptian shrine reveal the design method. A famous example, the so-called "Ghurob Shrine Papyrus", shows the use of a grid as guidelines for drawing the front and the side elevations of the shrine. It is noteworthy that the width of the post and the thickness of the lintel are designed to have exactly one square of the grid. The rest of the parts are defined as simple unit fractions $(1 / \mathrm{n})$ or the value added or subtracted by them $(1 \pm 1 / \mathrm{n})$. The second elevation drawing of a shrine is not drawn on a grid, but is drawn with notations of numbers and actual dimensions. The numbers are noted in demotic at each part of the shrine, again, the width of the post and the height of the lintel designated as "1". In both examples, the Egyptian system implies the use of a single module system.

Comparing the Egyptian and the Hellenistic module systems, the Doric system and Egyptian system used for shrines can be regarded as identical. The Ionic and other styles that evolved in the later period share the multi-modular system. The aim of such module systems was to adjust the appearance of the building, particularly the façade. Hence, it is natural that the use of the module concentrates on the elevation phase within the entire design process, and that it plays a less significant role in the prior phase of designing the plan and the overall size of the structure. 